\title{
SENSORY INTEGRATION IN POLAND AS A NEW AREA OF PRACTICE AND THEORY IN SOCIAL SCIENCES
}

\section{INTRODUCTION}

The presented article contains elementary metatheoretical information regarding sensory integration. It is related to its history, name, definition, and theoretical and methodological foundations, and they constitute answers to five questions. How was the concept of sensory integration created, and how was it developed? Where does the name "sensory integration" come from? How is it defined (understood)? On what theoretical and methodological foundations is the concept of sensory-integration based? And how are sensory integration disorders typologised?

The character of this article is elementary: it has a nature of a review, introduction, and reference. It does not solve the detailed issues related to sensory therapy, but rather gathers essential information explaining the essence of the methodological foundations of the concepts (!) of sensory integration. I think it is primarily important because sensory integration, regardless of the almost-thirty-years-old tradition of its practice in our country, is a new field of work, research and theory within the framework of social sciences. It has not developed (yet?) as an individual, autonomous, academic discipline, although it already meets some of the methodological criteria determining its academic nature. Finally, the need for it to be considered as part of the suggested field is justified by discussions and varied, at times radically expressed, assessments directed at sensory integration.

Piotr Magier, Phd - The Institute of Pedagogy, Faculty of Social Sciences, The John Paul II Catholic University of Lublin; ORCID: 0000-0002-9977-5214; correspondence address: e-mail: piotr.magier@kul.pl 
I am addressing this text to the readers interested in the development of social sciences, including sensory integration, in Poland. This applies both to the native Readers and the academics in other countries. For this reason, the article has been written in English. I think that the main readers of this work will be the methodologists and those practitioners who are interested in the methodological (meta-theoretical) aspects of functioning of social sciences.

The research material (typical for metatheoretical works), based on which this text has been developed, is source literature in Polish, both the texts of a Polish authors (Z. Przyrowski), as well as the translations of the works by A.J. Ayres - the creator of sensory integration - and its other classics, available to the Polish readers. Therefore, the comments I have formulated refer to the situation of sensory integration in Poland, but in my opinion, their significance can also apply to the situation of SI in other countries, and at least some of the issues referred to below are universal (general) in nature.

\section{THE GENESIS AND HISTORY \\ OF SENSORY INTEGRATION IN POLAND}

The authorship of the concept referred to as "sensory integration" is ascribed to an American born in Visalia (California) with a PhD in social sciences, Anna Jean Ayres (1920-1988). She initiated her academic career with a Bachelor's Degree (1945) and then a Master's Degree (1954) in occupational therapy in the field of proprioception. In the 1960s, as a scholarship holder at the American National Institute of Mental Health, together with Arthur H. Parmelee, PhD (1883-1961), she conducted studies on sensory information processing, which resulted in descriptions of sensory processing disorders (dysfunctions) in children. These studies became the foundations for her PhD (1961) in the field of educational psychology at the University of South California in Los Angeles. ${ }^{1}$

In the course of her university work Ms Ayres conducted lectures in the fields of pedagogy, special pedagogy, and occupational therapy. In the years 1968-1988 she developed and modified tools used to diagnose the processes of sensory integration: in 1972 she published the Southern California Sensory Integration Tests, and in 1975 the Southern California Postrotary Nystagmus

${ }^{1}$ Cf.: V.F. MAAS, Uczenie się przez zmysty [Learning through our senses], translated by D. Szatkowska, Gdańsk: Harmonia Universalis 2016, pp. 15-16. 
Test, while the Sensory Integration and Praxis Tests came out in 1989. Her abundant academic and therapeutic work (over one hundred articles, several books, two sets of diagnostic tests, continuous academic research, and therapeutic and educational activities) were awarded with the two highest distinctions of the American Occupational Therapy Association: the Eleanor Clarke Slagle Lectureship and the Award of Merit, as well as the Outstanding Educator of America Award, and the award of the PRSA - the Public Relations Society of America. A.J. Ayres was a member of numerous American associations and societies, such as the American Psychology Association, the American Occupational Therapy Association, the American Educational Research Association, and the Society for Research in Child Development. ${ }^{2}$

Apart from the research and academic work, the activities of A.J. Ayres were oriented to coaching specialists-sensory integration researchers and therapists. The group of her closest students included Violet F. Maas, Florence A. Clark, and Lucy Jean Miller. They contributed not only to the development of the research on sensory integration processes, but also on the worldwide dissemination of this concept, including in Poland.

It is acknowledged that the introduction of the concept of sensory integration in Poland occurred in the early 1990s, i.e. in the form of the educational and popularising activities of V.F. Maas conducted in Poland, inspired by Swiss therapist Mary Potter ${ }^{3}$. In September 1993, under the patronage of the Training Affairs Section of the National Committee for Aid to Children with Mobility Impairments at the Board of the Society of Friends of Children, the first course on sensory integration was organised in Helenów, prepared by Zbigniew Przyrowski and Maria Borkowska, conducted by V.F. Maas. ${ }^{4}$ On 15 November 1994 at the Provincial Court in Warsaw, the Polish Association of NDT-SI Therapists was registered, with Maria Borkowska acting as President. The board of the Association was composed of Małgorzata Matyja, Zofia Szwiling, Zbigniew Przyrowski, and Paweł Zawitkowski. The activities of the Association focused on the promotion of the sensory integration method and therapist training. That was also the year in which regular annual SI therapy training courses were initiated. The uniform sensory integration training model, based on the proposition of F.V. Maas, was developed in 1997, and covered three degrees: $1^{\text {st }}$ degree - the theoretical foundations of

\footnotetext{
${ }^{2}$ Cf.: ibid., pp. $15-16$.

${ }^{3}$ Cf.: ibid., p. 7.

${ }^{4}$ Cf.: http://pstis.pl/pl/html/index.php?vl=block\&str=podstrona_historia (accessed on 29/05/2019).
} 
sensory integration; $2^{\text {nd }}$ degree - teaching to conduct SI tests, interpreting the results of studies and developing the therapy plan; and the $3^{\text {rd }}$ degreeconducting the therapy. In 1997 Z. Przyrowski also translated the Southern California Sensory Integration Tests and adapted them to Polish conditions. ${ }^{5}$

A new stage in the activities of sensory integration therapists in Poland started in the year 2000. This is when on 27 January the Polish Association of Sensory Integration Therapists (PSTIS-SI), with its registered office in Warsaw, was filed at the Regional Court in Warsaw. Z. Przyrowski was elected President of the Association, and he held this position until 31 May 2008. The members of the board of PSTIS-SI included Małgorzata Karga and Magdalena Okrzasa, who, as well as Z. Przyrowski, are recognised as the most-merited people with regard to the animation and development of sensory integration therapy in Poland.

The activities of PSTIS-SI were based on the original sensory integration model developed by A.J. Ayres. Its emerge involved, among other things, awarding honorary membership to F.V. Maas (2000), creating Biuletyn SI [SI Bulletin] (2001), developing training courses, and educating sensory integration therapists, including the scope of disorders related to ADHD, PDD, autism, Williams syndrome, and Asperger syndrome, developing the concept of SI therapeutic work according to Winnie Dunn, developing the website and the library of the Association (2005), initiating cooperation with the Synapsis Association (2006), implementing the ODBK SI project-the Polish Nationwide Day of Free SI Consultation (on the initiative of Marta Wiśniewska of 2012), and creating a panel of free workshops and open lectures (2014). Since 2014 the position of President of PSTIS-SI has been held by Jolanta Kazanowska. ${ }^{6}$

At the moment there is no single institution (society, association) bringing together sensory integration therapists. The main ones include the Polish Association of Sensory Integration Therapists (PSTIS-SI), headed by J. Kazanowska, ${ }^{7}$ and the Polish Association of Sensory Integration (PTIS), headed by Iwona Palicka. ${ }^{8}$ Apart from their therapeutic and popularising activities, both these institutions instigate the education of sensory integration therapists. Although a licence to conduct SI diagnosis and therapy can be obtained by

\footnotetext{
${ }^{5}$ Ibid.

${ }^{6}$ Ibid.

${ }^{7}$ http://pstis.pl/pl/html/index.php?v1=block\&str=podstrona_zarzad (accessed on 07/06/2019).

${ }^{8}$ Cf.: http://www.integracjasensoryczna.org.pl/pl/wladze-ptis (accessed on 07/06/2019).
} 
persons with pedagogical and psychological education, special-education teachers, physiotherapists, and logopedists, based on completed postgraduate studies, ${ }^{9}$ both PSTIS-SI and PTIS certify the qualifications of sensory integration therapists, by establishing specific requirements and the content of the curricula of studies and courses, as well as by cooperating with international institutions operating in the field of SI therapy. ${ }^{10}$

\section{THE DEFINITION OF SENSORY INTEGRATION}

The fundamental difficulty in defining the essence of sensory integration consists in the lexical ambiguity of the Polish term "integracja sensoryczna" (in English "sensory integration"). ${ }^{11}$ Furthermore, ambiguities can be introduced by the presence of other names (apart from the above term, probably the most-often used in the Polish language) referring to the scope of child therapy and research analysed in this text. This applies in particular to the abbreviation SI, derived from the English term Sensory Integration, but also to such terms as "terapia ruchowa z wykorzystaniem technik (metody) SI" [in English "movement therapy using SI (method) techniques"]. Of no little importance to the precision of the understanding of these names and the identification of their designations is also the fact that they are not only descriptive, but also evaluative, in their meaning.

Although the recognised creator of the concept of SI, and therefore the populariser of the actual term "sensory integration," was A.J. Ayres (as I have already mentioned earlier), the introduction of this name into the academic literature is attributed to the British neurophysiologist, Sir Charles Scott Sherrington (1857-1952), who used it for the first time in 1902 in a book entitled The Integrative Action of the Nervous System. ${ }^{12}$

Analysis of the source literature allows us to formulate the thesis that the term "sensory integration" is attributed to four basic concepts. It is defined as 1) a system of nervous regulation, responsible for the reception, differen-

\footnotetext{
${ }^{9}$ Cf.: http://www.iwspo.pl/porady-prawne/prawo-oswiatowe/1363 (accessed on 10/09/2019).

${ }^{10} \mathrm{Cf}$.: https://pstis.pl/pl/html/?str=podstrona_certyfikat_terapeuty (accessed on 10/09/2019); http://www.integracjasensoryczna.org.pl/pl/O-kursach-SI (accessed on 10/09/2019).

${ }^{11}$ V.F. MAAS, Uczenie się przez zmysty [Learning through our senses], p. 28.

${ }^{12}$ Ibid., p. 18.
} 
tiation, processing, and interpretation of sensory stimuli; as 2) a concept $t^{13}$ describing the functioning of this system; 3) a therapeutic method, which aims to eliminate the disorders (dysfunctions) in the workings of sensory perception and processing; and also as 4) a type (system) of education preparing for conducting therapeutic activities within the scope of SI.

The original concept of sensory integration involved the first and second of the above terms. Such an understanding of "sensory integration" was introduced into the academic language by A.J. Ayres, ${ }^{14}$ and it happens that they are identified with each other (the concept is not differentiated from its object-in other words, the phenomenon from the concept which describes and explains it). Nevertheless, in the source literature and in common parlance the term "sensory integration" is also used with the other two meanings. Its use to designate a type of therapy in which the problem consists of sensory processing disorders seems equally (or maybe more) prevalent as the use in the first case. Its semantic specification is in this respect is supported by such specifying terms as "sensory integration therapy" and "the sensory integration method." The fourth understanding of the term "sensory integration" is, on the other hand, used in the educational and professional contexts. It is used in official titles and documents.

The term "sensory integration" is not limited to descriptive meaning (it specifies how sensory processing really, actually, occurs), but it also (primarily) has evaluative meaning, indicating the correctness, the optimal form of the course of these processes. A.J. Ayres wrote that it is about "[...] the most-important type of sensory processing." 15 This qualification introduces the standards with regard to sensory processing, assessment of its correctness or

\footnotetext{
${ }^{13}$ Although in the source literature the term used is "theory" and not "concept," I think that discussing the "theory of sensory integration" is overly "optimistic." I rather think that the level of coherence of this knowledge and the certainty of its justifications is not high enough to talk about a theory in this case cf.: Z. PRZYROWSKI, Integracja sensoryczna. Teoria, diagnoza, terapia [Sensory integration. Theory, diagnosis, therapy], Warszawa: Wydawnictwo EMPIS 2019, p. 20; J. KozIELECKI, Koncepcje psychologiczne czlowieka [Psychological concepts of a man], Warszawa: Wydawnictwo ŻAK 1996, pp. 16-17.

${ }^{14}$ It is for example contained in the following statement by Ayres. "Sensory integration is the organisation of sensations for use. Our senses give us information about the physical conditions of our body and the environment around us. Sensations flow into the brain like streams flowing into a lake." A.J. AYRES, Dziecko a integracja sensoryczna [Sensory Integration and the Child], translated by J. Okuniewski, Gdańsk: Harmonia Universalis 2015, p. 21; see also: Z. PrZYROwSKI, Integracja sensoryczna. Teoria, Diagnoza, Terapia [Sensory Integration. Theory, Diagnosis, Therapy], pp. 13-18.

${ }^{15}$ A.J. AYRES, Dziecko a integracja sensoryczna [Sensory Integration and the Child], p. 21.
} 
incorrectness, which in turn generates the problem of scope, validity (need), function, and types of assessments and standards used in social sciences. The normative understanding of "sensory integration" provokes a discussion concerning the evaluative (axiological) nature of these sciences, particularly in the context of contemporarily dominant (empirical) descriptive and explanatory approach. Furthermore, it introduces the questions concerning the need for the presence of theoretical, cultural, religious, and moral standards within their area. It also stimulates reflection on the contemporary (postmodern) culture of the West, promoting equality, pluralism and objection against stigmatising. ${ }^{16}$

What could be recognised as an attempt to solve the problem of normativity of the concept of sensory integration is the functional interpretation of the standards used within its framework and their typological nature. The evaluative concept of sensory integration introduced by Ayres specifies that the basic criterion for the assessment of the correctness of sensory integration processes is the functional criterion. "Sensory integration is the process of organising sensory inputs so that the brain produces a useful body, response and also useful perceptions, emotions, and thoughts." ${ }^{17}$ Although potentially different criteria of disorders can appear (e.g. disturbance in structure), only difficulties in sensory processing which generate further dysfunctions - cognitive, mobility, emotional, social—can be adopted as a basis for the designation of sensory integration disorders. ${ }^{18}$

In terms of content, the criterion used for assessing the correctness of sensory processing primarily relates to the category of the typicality of developmental milestones in children, which are in turn described in the field of developmental psychology and developmental neuropsychology. Other, auxiliary, criteria for the assessment of the degree of sensory integration, relating to the emotional, social, or educational functioning of a child, are used secondarily here. Furthermore, the use of the term "type" (typicality) relativises the adopted criteria. According to statistical (empirical) interpretation, this is about the most-often occurring developmental (especially functional) milestones in children at certain ages. The determination of deviations from the

\footnotetext{
${ }^{16}$ Cf. e.g. K.M BŁESZYŃSKA, Stygmatyzyacja [Stigmatisation], in: T. Pilch (ed.), Encyklopedia Pedagogiczna XXI wieku, vol. V, Warszawa: Wydawnictwo Akademickie Żak 2006, pp. 1102-1105.

${ }^{17}$ Ibid., p. 42.

${ }^{18}$ V.F. MAAS, Uczenie się przez zmysty [Learning through our senses], pp. 33-35.
} 
typological standard is not strict, and it can include intermediate situations, at the borderline between the standard and dysfunction, and therefore difficult to assess in an unambiguous manner. As a consequence, the applied standards are not dichotomous, but graded. This therefore refers to assessments within the framework of which we do not use only two, opposed, values (correct vs. incorrect degrees of sensory integration), but rather that we diversify this process in multiple degrees and multiple aspects. We can therefore discuss a different level of sensory integration, a different intensity of SI disorders, and their different types. Assessments of the correctness of sensory integration processes depend on the intensity of the stimulus, its type (proprioception, vestibule, superficial-sensation, vision, audition, gustation, olfaction) and from different kind, of patterns and configurations they occur in. ${ }^{19}$

As a result, the source literature defines different scopes and levels of sensory integration in children, and three main types of its disorders. Sensory integration can apply to different senses: olfaction, vision, audition, gustation, superficial sensation (touch), but most of all, deep sensation (proprioception), and the vestibular system. Furthermore, the objects of interest among SI therapists and researchers include the motor planning (praxis) and postural functioning of a child, bilateral coordination and crossing the body's midline, and fine and gross motor skills ${ }^{20}$. Furthermore, a significant aspect of sensory integration research and therapy covers dependencies (couplings) between the scope of sensory integration and the functioning of children with autism, ADHD disorders, foetal alcohol syndrome (FAS), dyslexia, intellectual disability, Down syndrome, and cerebral palsy. ${ }^{21}$

${ }^{19} \mathrm{~B}$. OdowsKa-SzLACHCic, Metoda integracji sensorycznej we wspomaganiu rozwoju mowy $u$ dzieci z uszkodzeniami ośrodkowego układu nerwowego [The sensory integration method in supporting speech development in children with central-nervous-system damage], Gdańsk: Wydawnictwo Harmonia 2016, pp. 28-29.

${ }^{20}$ Cf. e.g.: C.S. KRanowiTZ, Nie-zgrane dziecko $w$ świecie gier i zabaw. Zajęcia dla dzieci z zaburzeniami przetwarzania sensorycznego [The Out-of-Sync Child Has Fun. Activities for Kids with Sensory Processing Disorder], translated by J.A. Kamrowska, K. Majcher, P. Sorensen, Gdańsk: Wydawnictwo Harmonia Universalis 2015, pp. 29-30.

${ }^{21}$ Cf. e.g.: T. IRIKOwIC, H.C. Olson, S. AstLey, Stres rodzicielski i przetwarzania sensoryczne: dzieci ze spektrum alkoholowych zaburzen płodowych [Parenting Stress and Sensory Processing: Children With Foetal Alcohol Spectrum Disorders], translated by N. Smagacz, "Integracja Sensoryczna" no 1 (2019), pp. 12-22; Z. PRZYROWSKI, Integracja sensoryczna. Teoria, Diagnoza, Terapia [Sensory Integration.. Theory, Diagnosis, Therapy], pp. 163-223. 
Sensory integration disorders can apply both to the sense (system) to which they are related, and to the intensity of its functioning. The division of sensory integration disorders used most often divides them into three types: sensory modulation disorders, sensory discrimination disorders, and sensorybased-praxis disorders. Modulation disorders are also assigned to three types: children with sensory over-responsivity, children with sensory underresponsivity, and "sensory craving/seeking" children with sensory underresponsivity, whereas sensory-based motor disorders involve difficulties in motor planning (dyspraxia), and postural disorders. ${ }^{22}$

Children with sensory over-responsiveness (sensory defensiveness) are characterised by a high threshold of sensitivity to sensory stimuli. Even lowintensity stimuli have a strong impact on the nervous systems of these children. Though the acting stimuli are far lower in strength than the reactions, they do occur-non-specific fight-or-flight reactions (nervousness, aggression), or the opposite (avoidance, withdrawal). Difficulties with processing excessive amounts or excessively strong sensory stimuli mean that children with sensory over-responsiveness often isolate themselves from their physical or social surroundings, creating an isolated world, in which they feel safe; they also have difficulties with changes in activities in which they are participating. Both this situation, as well as excessive, often socially unaccepted, forms of reaction to the acting stimuli make the children with this type of sensory disorder easily noticed and stigmatised. ${ }^{23}$

Children with sensory under-responsivity have a low sensory-sensitivity threshold. This means that for the right (optimal) degree of stimulation on the central nervous system, these children need stronger stimuli or a longer time under their influence. A lack of sufficiently strong stimuli makes children with sensory under-responsivity apathetic, passive, "absent"; they prefer individual activities instead of group activities. They are often withdrawn, quiet and independent, which is why they avoid the attention of the adults. Nevertheless, in the situation of proper sensory stimulation, these children undertake constant, uncontrolled, activities aimed at the maintenance of the appropriate level of their sensory stimulation. These activities

\footnotetext{
${ }^{22}$ Cf.: L.J. Miller, Dzieci w świecie doznań. Jak pomóc dzieciom z zaburzeniami przetwarzania sensorycznego [Sensational Kids: Hope and Help for Children with Sensory Processing Disorder], translated by A. Pałynyczko-Ćwiklińska, Gdańsk: Wydawnictwo Harmonia Universalis 2016, pp. 65-92.

${ }^{23}$ Ibid., pp. 66-70.
} 
are referred to as the "difficulties with stopping" the behaviour providing sensory stimulation. ${ }^{24}$

This type, referred to as "a sensory seeker," is also characterised by a lowered sensory sensitivity threshold. However, children representing the described type of sensory integration disorder do not expect to be supplied with sensory experiences, but they provide themselves with this type of experiences. Constantly satisfying their needs for sensory stimulation, these children are perceived as "naughty," "fidgety," "hyperactive," "with ADHD," or even "aggressive." The need to supply sensory experiences is not limited to the motor area. Children with this type of under-sensitivity might prefer spicy dishes, strong smells, or loud noises. ${ }^{25}$

Sensory-discrimination disorders can be related to difficulties with recognising the type of stimulus affecting a child. They consist of difficulties with the assessment of whether a given stimulus affects an organism or whether its particular elements affect the individual. Children with sensorydiscrimination disorders can have difficulties with differentiating stimuli of a similar nature affecting different sensory systems, which can result in the impression that these children have developmental delays, or that they are cognitively impaired. ${ }^{26}$

Sensory-based motor disorders are related to difficulties in intending motions, and postural disorders. The underlying basis for this type of disorder is anomalies in the functioning of two senses-deep sensation and vestibular sense. Disorders in the interpretation of sensory stimuli from these two senses, and disorders in their coordination, mean the brain is not able to precisely determine the location of the child's body in space, and therefore to plan and make moves appropriate for a particular situation. As a consequence, children with sensory-based motor disorders have difficulties with translating the received senses into intending and making motions, especially in the case of multi-stage activities, unknown, new (dyspraxia), both within the scope of gross and fine motor skills (e.g. articulation problems); and within the scope of controlling their own bodies, also necessary to conduct their basic daily activities (postural disorders). Children with postural disorders have difficulties with maintaining the vertical trunk position, flaccidity within the scope of the shoulder girdle, arms and hands, and difficulties with writing. ${ }^{27}$

\footnotetext{
${ }^{24}$ Ibid., pp. $70-73$.

${ }^{25}$ Ibid., pp. $73-77$.

${ }^{26}$ Ibid., pp. $77-81$.

${ }^{27}$ Ibid., pp. 81-89.
} 
Regardless of the above-mentioned typology of sensory integration disorders, attention should be drawn to the fact that these disorders can appear as pure specific disorders, they can overlay with each other, ${ }^{28}$ and appear as disorders coupled with various other disorders of intellectual, emotional, and social functioning in children (non-specific), e.g. with epilepsy, brain damage, migraines, schizophrenia, anxiety states, autism, and ADHD. ${ }^{29}$ Multiple disorders can cause and intensify the symptoms of sensory integration disorders, but they can also conceal them, which impedes their diagnosis, and, in consequence, also therapy.

Concluding the analyses concerning the definition of sensory integration, it seems important to differentiate it from other forms of therapy. The ones that can be recognised as close to it are namely physiotherapy and occupational therapy. This activity is, however, unclear insofar as their terminological determinations, namely the ambiguity of each of the terms mentioned above. As a result, it is difficult to indicate a single model for relations between them.

In the broad understanding of the name "occupational therapy" both sensory integration (as also suggested by its origins) and physiotherapy can be treated as a form of occupational therapy. ${ }^{30}$ However, the narrow understanding of "occupational therapy" distinguishes it from other forms of therapy, treating occupational therapy as a form of therapy through work. ${ }^{31}$ Sensory integration in this perspective would gain a rank of a separate form of therapy (next to occupational therapy and physiotherapy), still remaining associated with them in terms of history and subject matter. What would distinguish sensory integration in terms of content would be the interest in sensory processing of various stimuli, both provided in the course of physical activities

${ }^{28}$ This occurs in the case of sensory-discrimination-modulation disorders and sensory-based motor disorders, in which it is estimated that modulation disorders (approx. 38\% of the tested persons) and sensory-based motor disorders (approx. $2 \%$ of the tested persons) occur in their pure form. Interestingly, researchers have not found any person with pure sensory-discrimination disorders ( $0 \%$ of the tested persons), cf.: ibid., p. 359.

${ }^{29}$ Ibid., pp. 365-387.

30 " [...] include different types of therapy conducted in the form of different activities, e.g. bibliotherapy, ludotherapy, art therapy, horticulotherapy": A. LESZCZYŃSKA-REJCHERT, Terapia Zajęciowa [Occupational Therapy], in: T. Pilch (ed.), Encyklopedia Pedagogiczna XXI wieku, vol. VI, Warszawa: Wydawnictwo Akademickie ŻAK 2007, p. 673.

31 "In a narrow meaning occupational therapy, also called ergotherapy or ergonotherapy (Gr. ergon-work) refers to specialised forms of rehabilitation taking form of activities in ceramic, sculpting, weaving workshops, etc.": ibid., p. 673. 
(not so much the physical exercises themselves, motor activity-physiotherapy), and the ones originating from various forms of manual or productive activity of an individual (narrow understanding of occupational therapy). The method of sensory stimuli processing, not the degree of physical functioning of the body or mastered manual skills would then determine the motor, cognitive, emotional and social functioning of an individual. ${ }^{32}$

\section{THE THEORETICAL AND METHODOLOGICAL FOUNDATIONS OF SENSORY INTEGRATION}

When characterising the concept of sensory integration, one cannot disregard the references to the theoretical assumptions based on which it has been developed. Their determination is not easy. They cover both the achievements of both natural and social (humanistic) sciences: medicine, psychology, pedagogy, physiotherapy, and logopaedics. Furthermore, the popularity gained by the sensory integration method results in numerous misunderstandings and its varied interpretations.

The texts authored by J.A. Ayres and other SI classics recognise the achievements of neuroanatomy and neurophysiology as the basic research reference points for the concept of sensory integration. The description of the functioning of the central and peripheral nervous system, in particular the process of the reception and transmission of sensory stimuli, its plasticity, needs and method of representation, and the interpretation of these stimuli in the brain, constitutes a basic element explaining the specificity of sensory integration and its disorders. Such an approach indicates that, although sensory integration is a complex and multi-faceted process, its essence (foundation) is of a biological nature, and it is related to the specificity of the functioning of the nervous system. ${ }^{33}$

Secondary, but significant, are the psychological, social and pedagogical foundations of the SI concept. They are basically related to the issues concerning the conditions, possibilities of stimulation, and consequences, of

${ }^{32}$ Cf.: K. Szamburski, Integracja sensoryczna [Sensory Integration], in: T. Pilch (ed.), Encyklopedia Pedagogiczna XXI wieku, vol. II, Warszawa: Wydawnictwo Akademickie ŻAK 2007, pp. 360-366.

${ }^{33}$ B. OdowsKa-SzLachCic, Metoda integracji sensorycznej we wspomaganiu rozwoju mowy [The sensory integration method in supporting speech development in children with central-nervous-system damage], pp. 28-29. 
sensory integration process disorders, because the development of biological mechanisms of sensory processing is not only conditioned by the correctness in the development of a child's biological organism, but also by the influence of psychological and social stimuli, as well as educational influences. Similarly, the consequences of the sensory functioning of an organism are not solely limited to biological aspects, but they are also related to the cognitive abilities, emotional, and social functioning of a child, and the child's achievements at school. This applies, for example, to graphomotor skills, the ability to focus attention, plan activities and implement the effectively, the ability to analyse and synthesise, openness to social interaction, acceptance of changes and other people, the ability to perform tasks and adjust to the norms, and even the appearance of aggressive behaviours. ${ }^{34}$

In the course of analysing A.J. Ayres' concept, it is difficult to locate further (deeper), theoretical (e.g. philosophical) assumptions on which it is based. Such information, expressed directly (explicite) cannot be found, at least in the Polish-language publications on sensory integration. Their content is mainly focused on the practical issues to such an extent that even if they contain paragraphs related to the theoretical foundations of sensory integration (e.g. if such a suggestion is included in the title of a paragraph or a chapter), their content is often poor in relation to the non-medical content, being usually limited to historical or biographical information, sometimes acting as a definition, or aspiring to play this role ${ }^{35}$. Similarly, in the source texts it is difficult to find any clues concerning its psychological or pedagogical conceptual origin. It seems to be inspired more by humanistic than by behavioural trends. The mentioned solution is supported by the postulate included in the publications on the subject, to follow the child and arrange the environment in a manner allowing optimal child development. ${ }^{36}$ Ultimately, the suggested solution is evaluative, and it is definitely disputable. ${ }^{37}$

${ }^{34}$ Cf.: Z. PrZYrowski, Integracja sensoryczna. Teoria, Diagnoza, Terapia [Sensory Integration. Theory, Diagnosis, Therapy], pp. 63-66.

${ }^{35}$ Cf. e.g.: B. ARNwINE, Rozpoczynanie terapii integracji sensorycznej [Starting Sensory Therapy], translated by K. Jaroszewski, Gdańsk: Wydawnictwo Harmonia Universalis 2016, p. 19; V.F. MAAS, Uczenie sie przez zmysty [Learning through our senses], pp. 18-23; Z. PRZYROWSKI, Integracja sensoryczna. Teoria, Diagnoza, Terapia [Sensory Integration. Theory, Diagnosis, Therapy], pp. 20-65.

36 "Only the child can integrate its nervous system; the therapist provides the nurturing environment". A.J. AYRES, Integracja sensoryczna a zaburzenia uczenia się [Sensory integration and learning disorders], Warszawa: Harmonia Universalis 2018, p. 341.

37 "Directed strategy is balancing between the directive and non-directive form of therapy. A therapist maintains a relative balance between these strategies, and in particular avoids 
The methodological aspect of the concept of sensory integration is more developed, emphasised in the texts of the creator of the concept of sensory integration A.J. Ayres, ${ }^{38}$ and present in the texts of her modern continuators. ${ }^{39}$ This is related to the criteria which are essential to the assessment of the academic status of this concept, such as the subject of research, research methodologies, language, history, academic administrative units, and achievements. ${ }^{40}$ It seems that not all of them are actualised by the concept of sensory integration. This applies in particular to the verifiable nature of statements confirmed by empirical studies, and the effects of sensory integration therapy, the existence of university-administration units, and the theoretical and meta-theoretical level of analyses it includes (or at least the awareness of the need to develop this type of reflection). It is also worrying that the classification of sensory integration disorders has not been officially published in the international nosological classifications. Sensory processing disorders (SPD) have not been taken into account, neither in the classification of diseases published by the American Psychiatric Association (DSM-V) nor in the International Classification of Diseases (ICD-10). ${ }^{41}$

Nevertheless, one can observe that some elements proving its academic aspirations have been developed within the framework of the concept. This

excessive direction, which can only lead to teaching passive copying of certain behaviour, and not a more-general change in the behaviour of a child". Z. PRZYROWSKI, Integracja sensoryczna. Teoria, Diagnoza, Terapia [Sensory Integration. Theory, Diagnosis, Therapy], p. 228.

${ }^{38}$ Cf. e.g.: A.J. AYRES, Integracja sensoryczna a zaburzenia uczenia się [Sensory integration and learning disorders], pp.15-22.

${ }^{39} \mathrm{Cf}$.: Reports from empirical studies on sensory functioning are published, for example, in the journal "Integracja Sensoryczna" [in English: "Sensory Integration"], in a special section entitled "Z badań naukowych" [in English: "From scientific research"], cf. e.g.: T.I. CABraL, L.G. Pereira de Silva, E. Tudella, C.M. Simões Martinez, Rozwój motoryczny a przetwarzanie sensoryczne: badanie porównawcze pomiędzy wcześniakami i dziećmi urodzonymi o czasie [Motor development and sensory processing. A comparative study between preterm and term infants], translated by N. Smagacz, "Integracja Sensoryczna" no 2 (2019), pp. 5-11; S.A. CERMAK, A.J. AYres, Przekraczanie linii środka ciała u dzieci z trudnościami w uczeniu się i u dzieci $w$ normie (dominacja ręki, integracja sensoryczna, lateralizacja) [Crossing the Body Midline in Learning-Disabled and Normal Children (hand dominance, laterality, sensory integration)], translated by N. Smagacz, "Integracja Sensoryczna" no 2 (2019), pp. 12-16.

${ }^{40}$ In this text I only refer more broadly to the criterion of the subject of research, research methods and language, cf.: A. BRONK, Czy pedagogika jest nauka autonomiczna? [Is pedagogy an autonomous science?], in: M. Nowak, T. Ożóg, A. Rynio, (ed.), W trosce o integralne wychowanie [Caring about integral education], Lublin: Wydawnictwo KUL 2003, pp. 63-65.

${ }^{41}$ An example of an analysis of SI disorders with reference to the indicators of the autism spectrum contained in DSM-5 conducted by Z. Przyrowski, cf.: Z. PRZYROwSKI, Integracja sensoryczna. Teoria, Diagnoza, Terapia [Sensory Integration. Theory, Diagnosis, Therapy], pp. 169-180. 
primarily applies to the genesis of this concept, which was based on "hard" natural (medical) science, and (it would seem clear, distinctive) indication of the subject of research specific to it-sensory processing. ${ }^{42}$

A.J. Ayres and her continuators have also not neglected the cognitive (diagnostic) aspect of the concept they created. As I have already mentioned earlier Ayres developed a range of tests used to diagnose sensory integration (disorders) in children. Furthermore, successive research tools were developed (modified) by other sensory integration therapists, including in Poland. To simplify, one can indicate three basic research techniques used as a standard in our country. These are: interviews with the parents of children, clinical monitoring of the children (Z. Przyrowski, M. Karga) and a range of Southern California Tests (A.J. Ayres). The SI diagnosis tools used in Poland are either translations of the tools developed by the classics of sensory integration (A.J. Ayres), or original developments of observation or interview questionnaires (Z. Przyrowski, M. Karga, M. Okrzasa). Significantly, some of these are subject to the standardisation procedure (Southern California Tests), but also to the restrictions on use due to the applicable copyrights and licences of the therapists. The above-mentioned diagnostic techniques utilise both the simple-survey and observation methods typical of humanities and the more-complex methods of functional diagnosis based on the determination of the physical dependency between a child's motor functioning and the neurophysiological processes conditioning this functioning. ${ }^{43}$

The remaining vulnerable element of the concept of sensory integration is its language. On one hand, specific terms originating from medical sciences are adopted within its field, and on the other hand it is driven by the ambiguous nomenclature of the humanities. Therefore, the precision of the "language of sensory integration" is not uniform. It can be observed in the descriptions of the functioning of children's bodies, especially involving neurophysiology and neuroanatomy, whereas in the aspect of the analyses of the emotional, social, and educational functioning of a child, conceptual

${ }^{42}$ A.J. AYReS, Dziecko a integracja sensoryczna [Sensory Integration and the Child], pp. 21-23.

${ }^{43}$ Cf.: Z. Przyrowski, Kliniczna obserwacja. Podręcznik [Clinical monitoring. A manual], Warszawa: EMPIS \& Sensum Mobile 2015; Z. PRZYROWSKI, Integracja sensoryczna. Teoria, Diagnoza, Terapia [Sensory Integration. Theory, Diagnosis, Therapy], pp. 66-106. The diagnostic methods used in sensory integration are discussed more broadly in the following publication: Z. PRZYrowsKi, Integracja sensoryczna. Teoria, Diagnoza, Terapia [Sensory Integration. Theory, Diagnosis, Therapy], pp. 66-107. 
inconsistencies are duplicated in as manner typical of the language of humanities. ${ }^{44}$

\section{CONCLUSIONS}

Sensory integration is a new field of practice and, in particular, research in the sphere of social sciences, especially in Poland. Although today it is recognised and identified, and even enjoys considerable popularity, its academic status does not seem to be clearly specified. Of course, the remaining issue is whether this type (i.e. academic) of embedding of the concept of sensory integration is needed, and what its potential purpose would be.

The solution to this problem is not simple. Specifically, it is related to the reliability and certainty (truthfulness) of particular knowledge, and the practice based on it. The indication is that this knowledge is not charlatanism, but rather that it leads to measurable and beneficial effects. However, assigning the rank of academic knowledge (concept) to sensory integration introduces certain requirements. This is not limited to the care for reliable practice in the therapist's profession, but primarily to care for the realisation of the criterion of "scholarship," expressed in the correctness of the application of research methods, precision of language, clear specification of the subject, and purpose of research. Its elements also include generating a theory embedded in the previous academic achievements-methodological and theoretical.

Problems of this type are definitely nothing new, and they have often appeared in the history of science. They have mainly applied to pioneering, freshly isolated (most often from philosophy) fields of knowledge, especially in the domain of the humanities. They have often achieved a certain level (type) of academic autonomy, although this is not a rule. In some cases, the academic status was abandoned, with the level of practical knowledge declared as satisfactory. ${ }^{45}$ This challenge applies to sensory integration, provided that its creators are interested in the "scholarship" aspect.

\footnotetext{
${ }^{44}$ Cf.: A.J. AYRES, Dziecko a integracja sensoryczna [Sensory Integration and the Child], pp. 20-23.

${ }^{45}$ In my opinion, this type of problem is still being faced by social work, cf.: P. MAGIER, Pedagogy and social work. The attempt to outline the range of mutual theoretical cooperation. The methodological context, in: L. Haburajová-Ilavská, K. Minarovičová, D. Baková (ed.), I. Vyšehradské Stretnutie "Sociálne Služby ako Pilier Európskej Spoločnosti“. Recenzovaný zborník
} 


\section{REFERENCES}

ARnwine, B. (2016). Rozpoczynanie terapii integracji sensorycznej [Starting Sensory Therapy]. Translated by K. Jaroszewski. Gdańsk: Harmonia Universalis.

Ayres, A.J. (2015). Dziecko a integracja sensoryczna [Sensory Integration and the Child] Translated by J. Okuniewski. Gdańsk: Harmonia Universalis.

AYRES, A.J. (2018). Integracja sensoryczna a zaburzenia uczenia się [Sensory integration and learning disorders]. Translated by J. Okuniewski. Warszawa: Harmonia Universalis.

BŁeszyŃsKa, K.M. (2006). Stygmatyzacja [Stigmatisation]. In: T. PILCH (ed.), Encyklopedia Pedagogiczna XXI wieku, vol. V (p. 1102-1105). Warszawa: Wydawnictwo Akademickie ŻAK.

BRonk, A. (2003). Czy pedagogika jest nauką autonomiczną? [Is pedagogy an autonomous science?]. In: M. NOWAK, T. OżóG, A. RYNIO, (ed.), W trosce o integralne wychowanie [Caring about integral education] (pp. 47-76). Lublin: Wydawnictwo KUL.

Cabral, T.I., Pereira de Silva, L.G., Tudella, E., Simões Martinez, C.M. (2019). Rozwój motoryczny a przetwarzanie sensoryczne: badanie porównawcze pomiędzy wcześniakami i dziećmi urodzonymi o czasie [Motor development and sensory processing: a comparative study between preterm and term infants] (pp. 5-11). Translated by N. Smagacz. Integracja Sensoryczna No. 2.

Cermak S.A., Ayres, A.J. (2019). Przekraczanie linii środka ciała u dzieci z trudnościami w uczeniu się i u dzieci w normie (dominacja ręki, integracja sensoryczna, lateralizacja) [Crossing the Body Midline in Learning-Disabled and Normal Children (hand dominance, laterality, sensory integration)]. Translated by N. Smagacz (pp. 12-16). Integracja Sensoryczna No. 2.

http://pstis.pl/pl/html/index.php?v1=block\&str=podstrona_historia (accessed on 29/05/2019).

http://pstis.pl/pl/html/index.php?v1=block\&str=podstrona_zarzad (accessed on 07/06/2019).

http://www.integracjasensoryczna.org.pl/pl/O-kursach-SI (accessed on 10/09/2019).

http://www.integracjasensoryczna.org.pl/pl/wladze-ptis (accessed on 07/06/2019).

http://www.iwspo.pl/porady-prawne/prawo-oswiatowe/1363 (10/09/2019).

https://pstis.pl/pl/html/?str=podstrona_certyfikat_terapeuty (accessed on 10/09/2019).

IRIKOWIC, T., Olson, H.C., Astley, S. (2019) Stres rodzicielski i przetwarzania sensoryczne: dzieci ze spektrum alkoholowych zaburzeń płodowych [Parenting Stress and Sensory Processing: Children With Fetal Alcohol Spectrum Disorders]. Translated by N. Smagacz (pp. 12-22). Integracja Sensoryczna No. 1.

Kozielecki, J. (1996) Koncepcje psychologiczne czlowieka [Psychological concepts of man]. Warszawa: Wydawnictwo ŻAK.

Kranowitz, C.S. (2015) Nie-zgrane dziecko w świecie gier i zabaw. Zajęcia dla dzieci z zaburzeniami przetwarzania sensorycznego [The Out-of-Sync Child Has Fun. Activities for Kids with Sensory Processing Disorder]. Translated by J.A. Kamrowska, K. Majcher, P. Sorensen. Gdańsk: Wydawnictwo Harmonia Universalis.

príspevkov z vedeckej konferencie s medzinárodnou účast’ou, ktorá sa uskutočnila na Univerzite Konštantína Filozofa v Nitre v dňoch 25.-26. apríla 2013, Nitra: Katedra sociálnej práce a sociálnych vied UKF v Nitre 2013, pp. 137-152. 
LESZCZYŃSKA-REJCherT, A. (2007) Terapia Zajęciowa [Occupational Therapy], in: T. Pilch (ed.), Encyklopedia Pedagogiczna XXI wieku. Vol. VI (pp. 673-678). Warszawa: Wydawnictwo Akademickie ŻAK.

MAAS, V.F. (2016) Uczenie się przez zmysty [Learning through our senses]. Translated by D. Szatkowska. Gdańsk: Harmonia Universalis.

Magier, P. (2013) Pedagogy and social work. The attempt to outline the range of mutual theoretical cooperation. The methodological context, in: L. Haburajová-Ilavská, K. Minarovičová, D. Baková (ed.), I. Vyšehradské Stretnutie "Sociálne Služby ako Pilier Európskej Spoločnosti“. Recenzovaný zborník príspevkov z vedeckej konferencie $\mathrm{s}$ medzinárodnou účast'ou, ktorá sa uskutočnila na Univerzite Konštantína Filozofa v Nitre v dňoch 25.-26. apríla 2013 (pp. 137-152). Nitra: Katedra sociálnej práce a sociálnych vied UKF v Nitre.

Miller, L.J. (2016) Dzieci w świecie doznań. Jak pomóc dzieciom z zaburzeniami przetwarzania sensorycznego [Sensational Kids: Hope and Help for Children with Sensory Processing Disorder]. Translated by A. Pałynyczko-Ćwiklińska. Gdańsk: Wydawnictwo Harmonia Universalis.

ODOwsKA-SzlaCHCIC, B. (2016) Metoda integracji sensorycznej we wspomaganiu rozwoju mowy u dzieci z uszkodzeniami ośrodkowego układu nerwowego [The sensory integration method in supporting speech development in children with central-nervous-system damage]. Gdańsk: Wydawnictwo Harmonia.

PrZYrowski, Z. (2019) Integracja sensoryczna. Teoria, diagnoza, terapia [Sensory integration. Theory, diagnosis, therapy]. Warszawa: Wydawnictwo EMPIS.

Przyrowski, Z. (2015) Kliniczna obserwacja. Podręcznik [Clinical monitoring. A manual]. Warszawa: EMPIS \& Sensum Mobile.

SzAMBURSKi, K. (2007) Integracja sensoryczna [Sensory integration], in: T. Pilch (ed.), Encyklopedia Pedagogiczna XXI wieku. Vol. II (pp. 360-366). Warszawa: Wydawnictwo Akademickie ŻAK.

\section{INTEGRACJA SENSORYCZNA W POLSCE JAKO NOWY OBSZAR PRAKTYKI I TEORII NAUK SPOŁECZNYCH}

Streszczenie

Przedmiotem artykułu jest jeden z najnowszych obszarów praktyki oraz badań prowadzonych na pograniczu nauk społecznych (psychologia, pedagogika) oraz medycyny - integracja sensoryczna. Celem artykułu jest opis podstawowych elementów definiujących integrację sensoryczną: dziejów, definicji, założeń teoretycznych i metodologicznych. Artykuł ma zatem charakter wprowadzający, porządkujący i metateoretyczny. Potrzebę badań w tym zakresie uzasadnia niejasny status poznawczy integracji sensorycznej, połączony z dużą popularnością tego zakresu wiedzy i praktyki terapeutycznej.

Słowa kluczowe: integracja sensoryczna; geneza i dzieje integracji sensorycznej; teoretyczne i metodologiczne podstawy integracji sensorycznej. 


\title{
SENSORY INTEGRATION IN POLAND AS A NEW AREA OF PRACTICE AND THEORY IN SOCIAL SCIENCES
}

\begin{abstract}
Summary
The subject of this article is one of the most-recent additions to the field of practice and research conducted on the borderline between social sciences-psychology, pedagogy — and medicine-sensory integration. The purpose of this article is to describe the basic elements defining sensory integration: history, definitions, and theoretical and methodological assumptions. The nature of this article is therefore introductory, referential, and metatheoretical. The need for research in this field is justified by the unclear cognitive status of sensory integration, combined with the great popularity of this sphere of therapeutic practice and knowledge.
\end{abstract}

Key words: sensory integration; genesis and history of sensory integration; theoretical and methodological foundations of sensory integration. 